\title{
Cholinergic Regulation of hnRNPA2/B1 Translation by M1 Muscarinic Receptors
}

\author{
Benjamin Kolisnyk, ${ }^{1,2}$ Mohammed A. Al-Onaizi, ${ }^{1,4}$ Jason Xu, ${ }^{1,4}$ Gustavo M. Parfitt, ${ }^{1}$ Valeriy G. Ostapchenko, ${ }^{1,3}$ \\ Geula Hanin, ${ }^{5,6}$ Hermona Soreq, ${ }^{5,6}$ Marco A. M. Prado, ${ }^{1,2,3,4}$ and $\mathbb{C V}^{-V a n i a}$ F. Prado ${ }^{1,2,3,4}$ \\ ${ }^{1}$ Robarts Research Institute, Schulich School of Medicine and Dentistry, University of Western Ontario, London, Ontario, Canada N6A5K8, and ${ }^{2}$ Graduate \\ Program in Neuroscience, Departments of ${ }^{3}$ Physiology and Pharmacology and ${ }^{4}$ Anatomy and Cell Biology, ${ }^{5}$ The Edmond and Lily Safra Center for Brain \\ Sciences, and ${ }^{6}$ The Silberman Institute of Life Sciences, The Hebrew University of Jerusalem, Jerusalem, Israel 91904
}

Cholinergic vulnerability, characterized by loss of acetylcholine (ACh), is one of the hallmarks of Alzheimer's disease (AD). Previous work has suggested that decreased $\mathrm{ACh}$ activity in $\mathrm{AD}$ may contribute to pathological changes through global alterations in alternative splicing. This occurs, at least partially, via the regulation of the expression of a critical protein family in RNA processing, heterogeneous nuclear ribonucleoprotein (hnRNP) A/B proteins. These proteins regulate several steps of RNA metabolism, including alternative splicing, RNA trafficking, miRNA export, and gene expression, providing multilevel surveillance in RNA functions. To investigate the mechanism by which cholinergic tone regulates hnRNPA2/B1 expression, we used a combination of genetic mouse models and in vivo and in vitro techniques. Decreasing cholinergic tone reduced levels of hnRNPA2/B1, whereas increasing cholinergic signaling in vivo increased expression of hnRNPA2/B1. This effect was not due to decreased hnRNPA2/B1 mRNA expression, increased aggregation, or degradation of the protein, but rather to decreased mRNA translation by nonsense-mediated decay regulation of translation. Cell culture and knockout mice experiments demonstrated that M1 muscarinic signaling is critical for cholinergic control of hnRNPA2/B1 protein levels. Our experiments suggest an intricate regulation of $\mathrm{hnRNPA} / \mathrm{B} 1$ levels by cholinergic activity that interferes with alternative splicing in targeted neurons mimicking deficits found in AD.

Key words: Alzheimer's disease; acetylcholine; alternative splicing; hippocampus; VAChT

Significance Statement

In Alzheimer's disease, degeneration of basal forebrain cholinergic neurons is an early event. These neurons communicate with target cells and regulate their long-term activity by poorly understood mechanisms. Recently, the splicing factor hnRNPA2/B, which is decreased in Alzheimer's disease, was implicated as a potential mediator of long-term cholinergic regulation. Here, we demonstrate a mechanism by which cholinergic signaling controls the translation of hnRNPA2/B1 mRNA by activation of M1 muscarinic type receptors. Loss of cholinergic activity can have profound effects in target cells by modulating hnRNPA2/B1 levels.

\section{Introduction}

Dementia affects roughly 44 million individuals worldwide and represents a large economic burden (Wimo et al., 2013). Individ-

Received Dec. 24, 2015; revised April 22, 2016; accepted May 2, 2016.

Author contributions: B.K., V.G.O., G.H., H.S., M.A.M.P., and V.F.P. designed research; B.K., M.A.-0., J.X., and G.M.P. performed research; G.H. contributed unpublished reagents/analytic tools; B.K. and M.A.-0. analyzed data; B.K., M.A.-0., M.A.M.P., and V.F.P. wrote the paper.

This work was supported by the Canadian Institute of Health Research (MOP 136930, MOP 126000, and MOP 89919), Natural Sciences and Engineering Research Council of Canada (402524-2013), Brain Canada, the Canadian Foundation for Innovation, and the Ontario research fund (M.A.M.P., V.F.P.); the European Research Council (Advanced Award 321501) and the Legacy Heritage Science Initiative of the Israel Science Foundation (Grant 378/11) (H.S.); and an Annie Darkens Research Fund Award from the Alzheimer's Society of Canada Fellowship (B.K.). M.A.A.-0. received fellowship support from Kuwait University, and G.M.P. was a recipient of a Science without Borders fellowship from the Brazilian government. We thank Dr. Jurgen Wess, National Institute of Diabetes and Digestive and Kidney Diseases, National Institutes of Health, for providing M1 and M4 knockout mice.

The authors declare no competing financial interests. uals affected with Alzheimer's disease (AD) present a profound decrease in basal forebrain cholinergic neurons (Whitehouse et al., 1982). These findings led to the cholinergic hypothesis of AD and the use of cholinesterase inhibitors to mitigate cholinergic failure (Bartus et al., 1982). Previous work suggests that the use of cholinesterase inhibitors for one year in possible prodromal ADaffected individuals halved rates of hippocampal atrophy, suggesting an intricate relationship between cholinergic tone and neurodegeneration (Dubois et al., 2015).

Cholinergic tone can modulate signal processing by changing electrical properties of cells and by modulating intracellular sig-

Correspondence should be addressed to either Marco Prado or Vania Prado, The University of Western Ontario, 1151 Richmond Street North, London, Ontario, Canada N6A 5B7.E-mail: mprado@robarts.ca or vprado@robarts.ca. D0I:10.1523/JNEUROSCI.4614-15.2016

Copyright $\odot 2016$ the authors $\quad 0270-6474 / 16 / 366287-10 \$ 15.00 / 0$ 
naling (Dajas-Bailador and Wonnacott, 2004; Soreq, 2015). In addition, it has become clear that cholinergic signaling can also regulate long-term gene expression, miRNAs (Shaked et al., 2009; Soreq, 2015), and alternative splicing (Berson et al., 2012; Kolisnyk et al., 2013a), all of which can modulate functional properties of cells (Blencowe, 2006; Novarino et al., 2014). A key protein that regulates splicing events in $\mathrm{AD}$ is the heterogeneous nuclear ribonucleoprotein (hnRNP) A2/B1, which is reduced in brains of $\mathrm{AD}$ patients due to cholinergic deficiency (Berson et al., 2012; Kolisnyk et al., 2013a) and is reduced in mice with a conditional deletion of the vesicular acetylcholine (ACh) transporter in the forebrain (VAChT) (Kolisnyk et al., 2013a).

hnRNPs are a large family of proteins that package pre-mRNA into larger hnRNP particles (Dreyfuss et al., 1993). Each of the hnRNPs contain distinct RNA binding motifs, which allows them to exert their roles in pre-mRNA processing (Weighardt et al., 1996; Black, 2003). hnRNPA2/B1 is one of the major hnRNP isoforms in the brain regulating alternative splicing and the transport of mRNA to distal cellular processes (Han et al., 2010). Importantly, knockdown of hnRNPA2/B1 in vivo caused impairments in learning and memory (Berson et al., 2012). Together, these findings suggest a critical role for this RNA binding protein in neuronal function and cognition.

Previous work suggests that cholinergic tone can regulate levels of hnRNPA2/B1; however, the mechanisms involved are unclear. Here, we show that hnRNPA2/B1 is a cholinergic controlled splicing factor. M1 muscarinic receptor activity is critical for cholinergic regulation of hnRNPA2B1 translation. This work provides a new mechanism by which acetylcholine can influence targeted neurons, leading to potential widespread changes in neuronal function.

\section{Materials and Methods}

Mouse lines. All animals with targeted elimination of VAChT were generated using the VAChT ${ }^{\text {flox/flox }}$ mouse described by Martins-Silva et al. (2011). To eliminate VAChT from the forebrain, $\mathrm{VAChT}^{\text {flox/flox }}$ mice were crossed with C57BL/6J-Tg(Nkx2-1-cre)2Sand/J mice (Xu et al., 2008) to generate

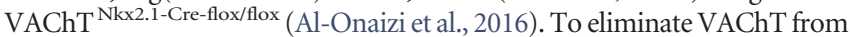
the striatum, the VAChT ${ }^{\text {flox/llox }}$ mice were crossed with D2-Cre mice (Drd2, line ER44) to generate VAChT ${ }^{\text {D2-Cre-flox/llox }}$ (Guzman et al., 2011). VAChToverexpressing ChAT-ChR2-EYFP mice were from The Jackson Laboratory [B6.Cg-Tg(Chat-Cop4 ${ }^{\star}$ H134R/EYFP)6Gfng/J; Zhao et al., 2011]. Generation of TgR (Shaked et al., 2009), M1 KO (Hamilton et al., 1997), and M4 KO mice (Gomeza et al., 1999) was described previously. All procedures were conducted in accordance with guidelines of the Canadian Council of Animal Care at the University of Western Ontario with an approved institutional animal protocol (2008-127). Only male mice were used for all experiments.

Immunofluorescence. Immunofluorescence experiments were performed as described previously (Guzman et al., 2011). Primary antibodies used were anti-hnRNPA2/B1 (1:200; Santa Cruz Biotechnology, catalog \#sc-10035), anti-NeuN (1:200; PhosphoSolutions, catalog \#583FOX3), and anti-GFAP (1:500; Abcam, catalog \#ab7260). Sections were visualized with a Zeiss LSM 510 Meta confocal system $(10 \times, 40 \times$, and $63 \times$ objectives), and a $488 \mathrm{~nm}$ Ar laser and $633 \mathrm{~nm}$ HeNe laser were used for excitation of fluorophores.

Western blotting. Mouse hippocampi were collected, proteins were isolated, and immunoblotting was performed as described previously using RIPA lysis buffer supplemented with protease and phosphatase inhibitors (Guzman et al., 2011). Band intensities were quantified using FluoroChemQ software (Thermo Fisher Scientific).

Subcellular fractionation. To isolate nuclear and cytoplasmic proteins from hippocampal tissue, the NE-PER Nuclear Protein Extraction Kit (Thermo Fisher Scientific) was used following the manufacturer's instructions.

Sarkosyl insolubility. Isolation of sarkosyl-insoluble protein was performed as described previously (Bai et al., 2013). Hippocampal tissue was homogenized in a low salt buffer [10 mm Tris, pH 7.5, 5 mm EDTA, 1 mm
DTT, $10 \%(\mathrm{w} / \mathrm{v})$ sucrose, Sigma protease inhibitor cocktail; $\sim 10 \mathrm{ml}$ buffer per gram tissue] to detect total protein, a detergent buffer [the low salt buffer with the addition of $1 \%(\mathrm{w} / \mathrm{v})$ sarkosyl ( $N$-lauroylsarcosine)] for the sarkosyl-soluble fraction, and finally $8 \mathrm{~m}$ urea with $2 \%$ (w/v) SDS for the sarkosyl-insoluble fraction.

Ubiquitination assay. The ubiquitination status of the hnRNPA2/B1 protein was determined using previously described protocols (Choo and Zhang, 2009). Briefly, the hnRNPA2/B1 protein was immunoprecipitated using the Santa Cruz Biotechnology (catalog \#sc-10035) antibody and run on an SDS-PAGE gel. The gel was then blotted with an antiubiquitin antibody (Abcam, catalog \#ab7780).

Stereotaxic injections of adeno-associated virus. Injection of AAV virus was described previously (Al-Onaizi et al., 2016). Briefly, mice were anesthetized with ketamine $(100 \mathrm{mg} / \mathrm{kg})$ and xylazine $(25 \mathrm{mg} / \mathrm{kg})$, and $1 \mu \mathrm{l}$ (titer of $\sim 1013$ Gene Copies/ml) of AAV8-GFP-Cre or control virus (AAV8-GFP, Vector BioLabs) was injected into the medial septum $(0.98$ anteroposterior, 0.1 laterolateral, and 4.1 dorsoventral) of VAChT flox/flox mice. A recovery period of 4 weeks was given to allow transgene expression before subsequent analyses.

RNA sequencing. Total RNA was extracted from hippocampal tissues. The cDNA library was prepared using a TruSeq Stranded Total Sample Preparation kit (Illumina) and run in a HiSeq 2500 platform. Data sets are available on ArrayExpress (http://www.ebi.ac.uk/arrayexpress/) under accession number E-MTAB-3897.

$q P C R$ and $R T-P C R$. To measure mRNA expression, total RNA was extracted from freshly dissected hippocampal tissue using the Aurum Total RNA for Fatty and Fibrous Tissue kit (Bio-Rad) according to the manufacturer's instructions. cDNA synthesis and qPCR analysis were performed as described previously (Guzman et al., 2011). For alternative splicing experiments, the alternative exon levels were normalized to a constitutively expressed exon from the same gene. RT-PCR was performed as described previously (Ribeiro et al., 2007).

Isolation of polysomal RNA. Isolation of polysomal RNA was performed as described previously (Wagnon et al., 2012). Samples were homogenized in $1.5 \mathrm{ml}$ of ice-cold lysis buffer [ $20 \mathrm{~mm}$ Tris- $\mathrm{HCl}, \mathrm{pH} 7.4$, $3 \mathrm{~mm} \mathrm{MgCl}_{2}, 10 \mathrm{~mm} \mathrm{NaCl}, 2 \%$ sucrose, $0.3 \%$ Triton X-100, 2 mm vanadyl ribonucleoside complexes (VRCs)] supplemented with protease inhibitors (cOmplete, mini, EDTA-free, Roche). The homogenate was then centrifuged at $10,000 \times g$ for $10 \mathrm{~min}$ at $4^{\circ} \mathrm{C}$, and the supernatant was transferred to a fresh tube. The lysate was treated with either $30 \mathrm{~mm}$ EDTA or $0.1 \mathrm{mg} / \mathrm{ml}$ RNase A for $30 \mathrm{~min}$ on ice; if it was to be treated with EDTA, VRCs were not included in the lysis buffer. Lysate was then carefully layered onto $15-55 \%$ of sucrose in $25 \mathrm{~mm}$ Tris- $\mathrm{HCl}, \mathrm{pH} 7.4,25 \mathrm{~mm}$ $\mathrm{NaCl}, 5 \mathrm{~mm} \mathrm{MgCl}$ (and $30 \mathrm{~mm}$ EDTA for the EDTA samples). Gradients were ultracentrifuged in a Beckman Instruments SW40Ti rotor at $150,000 \times g$ for $2 \mathrm{~h}$ and $25 \mathrm{~min}$ at $4^{\circ} \mathrm{C}$.

To isolate RNA from the fractions, RNA was collected into $1.5 \mathrm{ml}$ of $7.7 \mathrm{M}$ guanidine- $\mathrm{HCl}, 2 \mathrm{ml}$ of $100 \%$ ethanol was added, and samples were stored at $-20^{\circ} \mathrm{C}$. Samples were then centrifuged at $4000 \times g$ for $50 \mathrm{~min}$ at $4^{\circ} \mathrm{C}$. The supernatant was removed, and $200 \mu \mathrm{l}$ DEPC-treated $\mathrm{H}_{2} \mathrm{O}$ was added to the pellet. To precipitate the RNA, $500 \mu$ l of $100 \%$ ethanol, $20 \mu \mathrm{l}$ of $3 \mathrm{M}$ sodium acetate, $\mathrm{pH} 5.2$, and $10 \mu \mathrm{g}$ glycogen were added, and the samples were stored overnight at $-20^{\circ} \mathrm{C}$. The samples were then centrifuged at $14,000 \times g$ for $30 \mathrm{~min}$ at $4^{\circ} \mathrm{C}$. Pellets were washed with ice-cold $75 \%$ ethanol and air dried for $15 \mathrm{~min}$ at room temperature. RNA was resuspended in $30 \mu \mathrm{l}$ DEPC-treated $\mathrm{H}_{2} \mathrm{O}$ and quantified by nanodrop before being converted into cDNA using the Applied Biosystems cDNA conversion kit. RT-PCR was then performed using primers designed to amplify hnRNPA2/B1 or $\beta$-Actin.

Primary neuronal cultures. Primary cultures of hippocampal neurons from embryonic day 17 mouse embryos were obtained as described previously (Beraldo et al., 2013). Cultures were maintained in Neurobasal medium with $2 \%$ B-27 supplement (Invitrogen). On day 4, cytosine arabinoside ( $2 \mu \mathrm{M}$; Sigma) was added to prevent astrocyte growth. Half of the culture medium was changed every 2 or $3 \mathrm{~d}$. Neurons were cultured for $15 \mathrm{~d}$.

Pharmacological manipulations in primary neuronal cultures. On the 15 th day of culture, neurons were treated with different doses of carbachol $(0,5,10$, or $50 \mu \mathrm{M})$ dissolved in saline, and $48 \mathrm{~h}$ later, total protein 
A

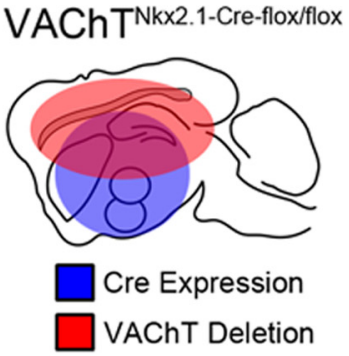

C

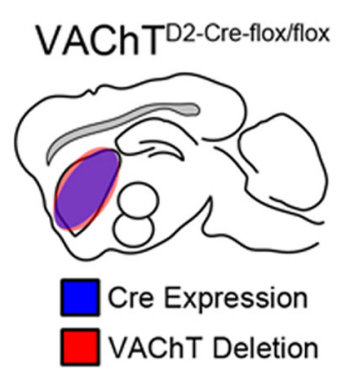

VAChT $T^{\text {floxfmox }}$ VAChT $T^{\text {Nkx2.1-Cre-floxflox }}$ hnRNPA2/B1

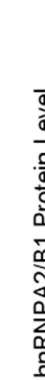

B
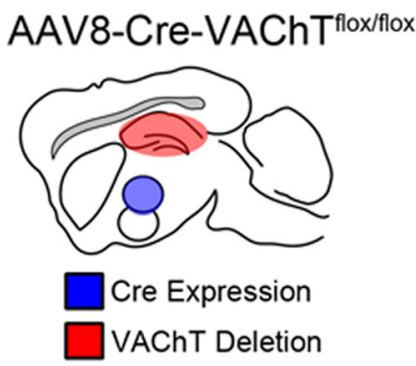

D

VAChT $T^{\text {floxfflox }}$ VAChT $T^{\mathrm{D} 2 \text {-Cre-floxfflox }}$
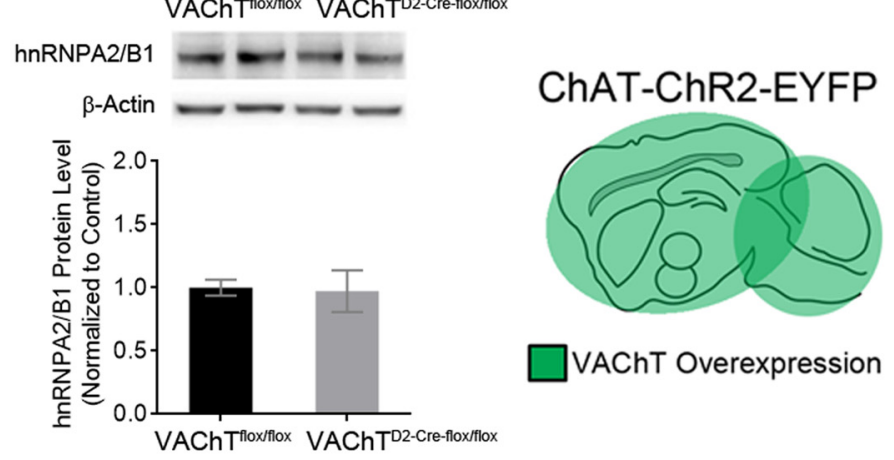

$\mathbf{F}$
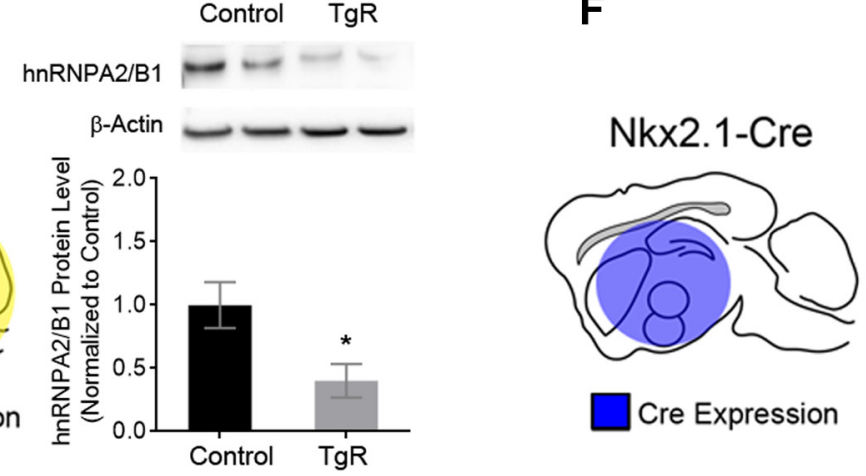
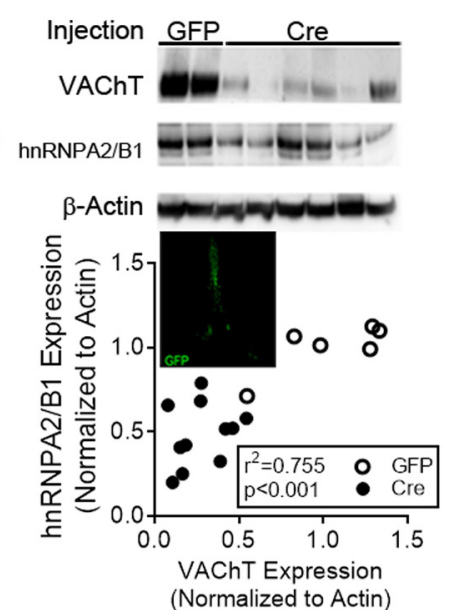

Control ChAT-ChR2-EYFP

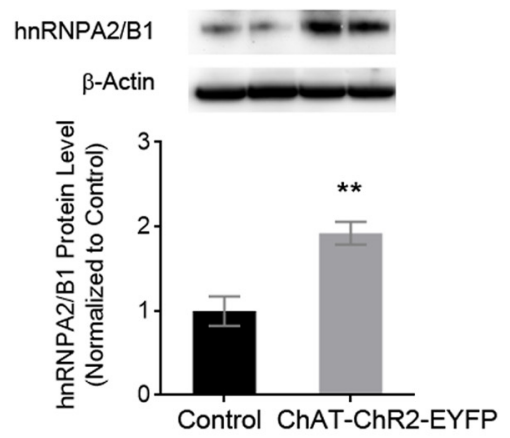

$\mathbf{E}$

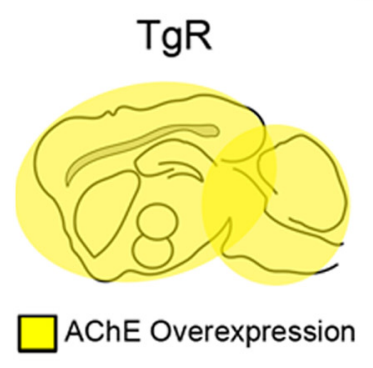

Figure 1. Analysis of hnRNPA2/B1 protein levels in genetically modified mice with differential expression of VAChT. $A$, Representative Western blot and quantification of hnRNPA2/B1 protein expression in the hippocampus of VAChT ${ }^{\text {flox/flox }}$ and VAChT ${ }^{\text {Nkx2.1-Cre-flox/flox }}$ mice. hnRNPA2/B1 expression was normalized to actin $(n=6)$. $B$, hnRNPA2/B1 protein levels positively correlate with AAV induced reduction of VAChT. The graph shows values for each individual mice injected either with GFP or CRE. The image is from the medial septum of a virus-injected mice. $C$, Striatal elimination of VAChT does not alter hnRNPA2/B1 protein levels in the striatum of VAChT ${ }^{\text {D2-Cre-flox/flox }}$ mice $(n=4)$. D, Transgenic mice overexpressing VAChT have increased hnRNPA2/B1 protein levels compared to controls $(n=4)$. $\boldsymbol{E}$, hnRNPA2/B1 protein levels from the hippocampus of TgR transgenic mice $(n=3)$. $\boldsymbol{F}$, No change in hnRNPA2/B1 protein levels compared to controls in the hippocampus of c567BL/6J-Nkx2.1-Cre mice $(n=3)$. Data are mean \pm SEM. ${ }^{*} p<0.05 ;{ }^{* *} p<0.01$.

was isolated and levels of hnRNPA2/B1 were determined by Western blotting and immunofluorescence. To evaluate the contribution of nicotinic and muscarinic receptors in regulating hnRNPA2/B1 protein levels, neurons were pretreated with mechamylamine $(100 \mu \mathrm{M})$, atropine $(100 \mu \mathrm{M})$, or both. Then, $1 \mathrm{~h}$ later, neurons were treated with carbachol $(10 \mu \mathrm{M})$. Finally, to assess the effect of M1 muscarinic activation, neurons were treated with different doses of $\operatorname{AF} 102 \mathrm{~B}(0,10$, or $100 \mu \mathrm{M})$ dissolved in saline.

Statistical analysis. Data are presented as mean \pm SEM unless otherwise stated. GraphPad Prism 6 software was used for statistical analysis. Comparison between two experimental groups was done by Student's $t$ test. When several experimental groups or treatments were analyzed, one-way ANOVA and, when appropriate, a Tukey's HSD post hoc comparison test were used.

\section{Results}

Cholinergic modulation of hnRNPA2/B1 protein levels

Previous experiments indicated that hnRNPA2/B1 is decreased in $\mathrm{AD}$ brains, but this is not modeled in genetic mouse models of AD (Berson et al., 2012). In contrast, either genetic or immunotoxin disruption of cholinergic tone led to decreased expression of hnRNPA2/B1 (Berson et al., 2012; Kolisnyk et al., 2013a). As 

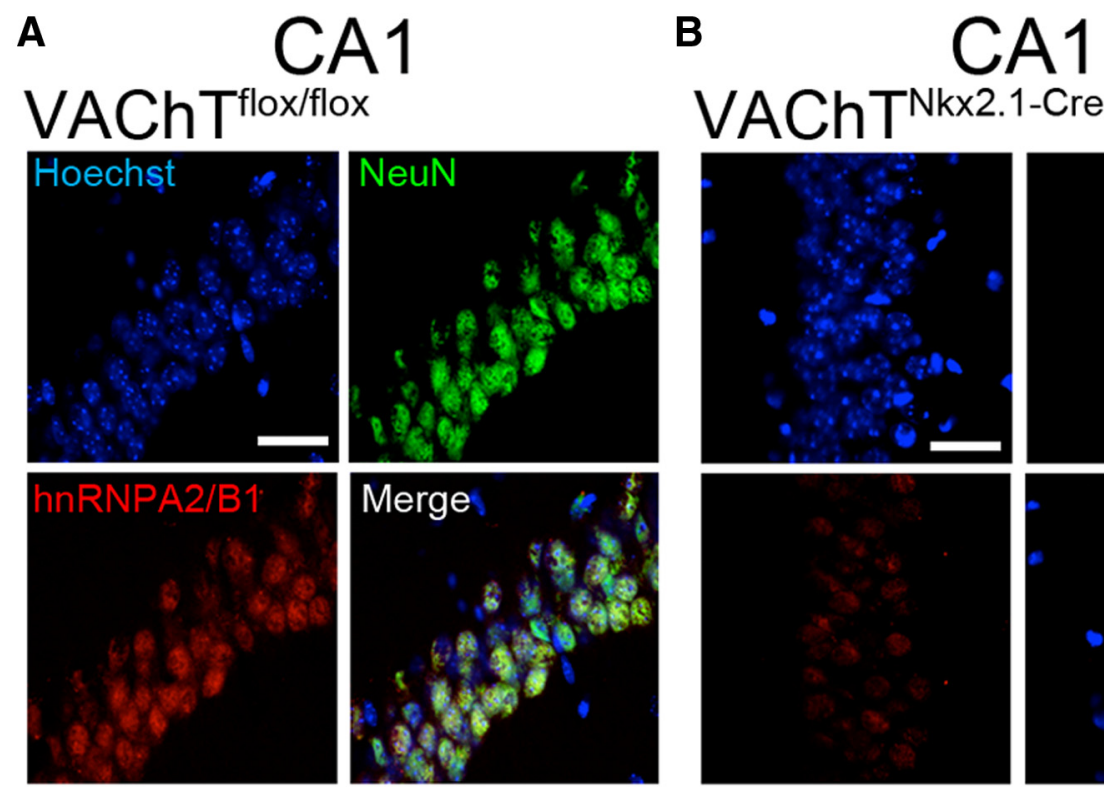

VAChT Nkx2.1-Cre-flox/flox
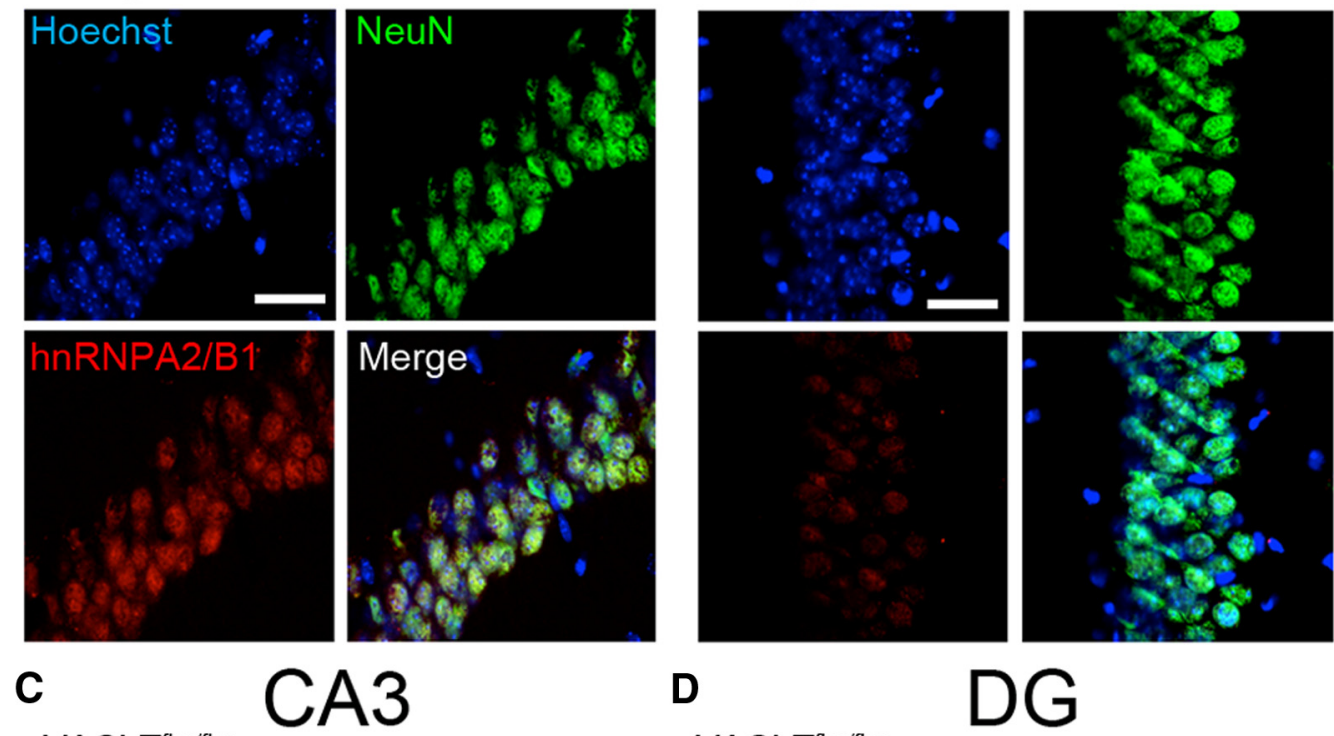

VAChT floxflox

\section{D}
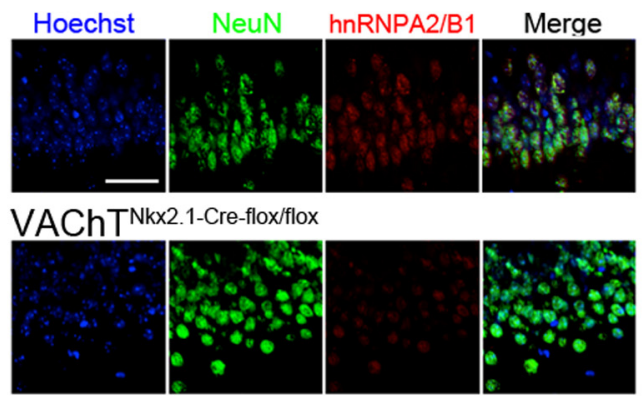

VAChT $T^{\text {flox/flox }}$
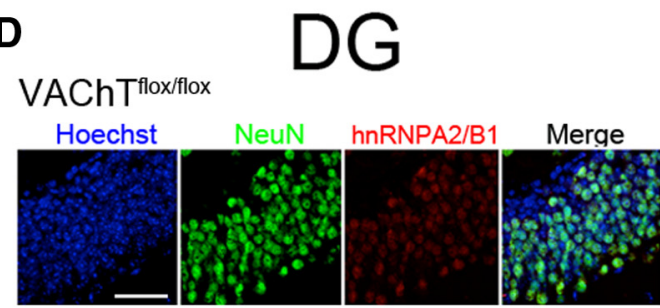

VAChT ${ }^{\text {Nkx2.1-Cre-floxfllox }}$

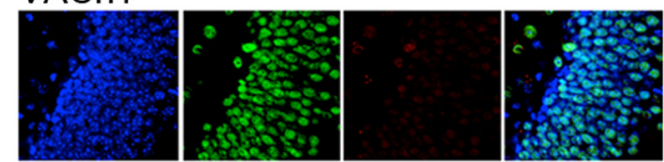

E

$\mathbf{F}$
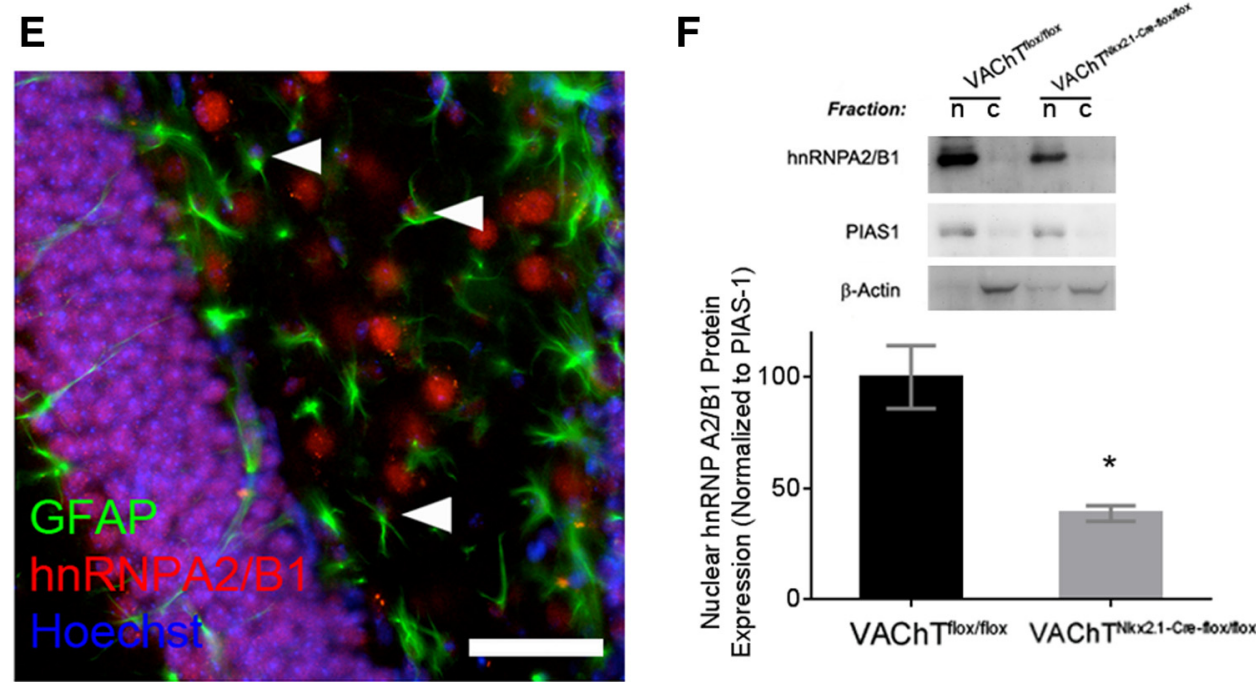

Figure 2. Characterization of decreased hnRNPA2/B1 protein levels in the hippocampus of VAChT-deficient mice. $A, B$, Representative images of slices stained for NeuN, hnRNPA2/B1 and Hoeschst in the CA1 region of the hippocampus in controls $(\boldsymbol{A})$ and VAChT ${ }^{\mathrm{Nkx2} .1-\mathrm{cre} \text {-flox/flox }}$ mice $(\boldsymbol{B})$. $\boldsymbol{C}, \boldsymbol{D}$, Expression of hnRNPA2/B1 in the $C A 3(\boldsymbol{C})$ and dentate gyrus (D) by immunofluorescence reveals general decrease of the protein and nuclear localization in VAChT-deficient mice. $E$, Localization of hnRNPA2/B1 with GFAP glial marker in the hippocampus of VAChT ${ }^{\text {Nkx2.1-Cre-flox/flox }}$ mice (arrowheads). $F$, Subcellular fractionation assay of hnRNPA2/B1 protein shows that hnRNPA2/B1 is mainly nuclear. Scale bars: $50 \mu \mathrm{m}$. Data are mean \pm SEM. ${ }^{*} p<0.05$.

expected, VAChT ${ }^{\text {Nkx2.1-Cre-flox/flox }}$ animals presented a robust decrease in hnRNPA2/B1 levels in the hippocampus (Fig. 1A).

The Nk2.1 promoter turns on Cre expression early during development (Xu et al., 2008), and, therefore, the resulting decrease in hnRNPA2/B1 levels could potentially be a result of de- velopmental suppression of cholinergic tone, rather than being cholinergic regulated in adult mice. To test this possibility, we deleted the VAChT gene specifically in medial septum neurons and parts of the diagonal band (Al-Onaizi et al., 2016), which provides most of the hippocampal cholinergic innervation, of 


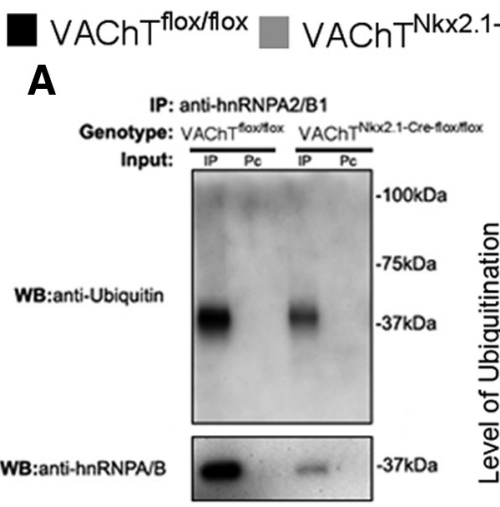

D

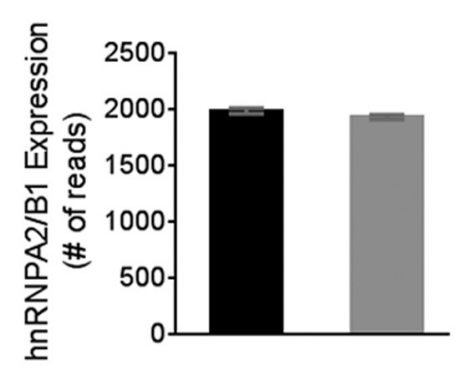

B

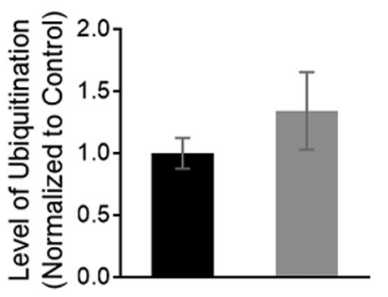

E hnRNPA2/B1 3' UTR

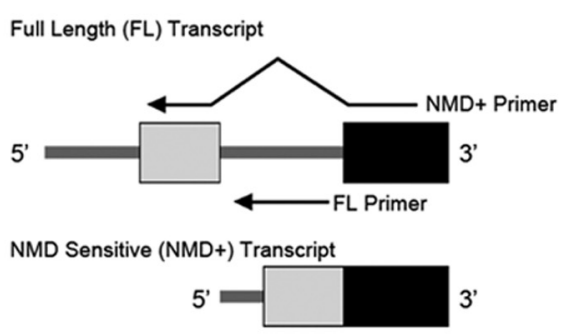

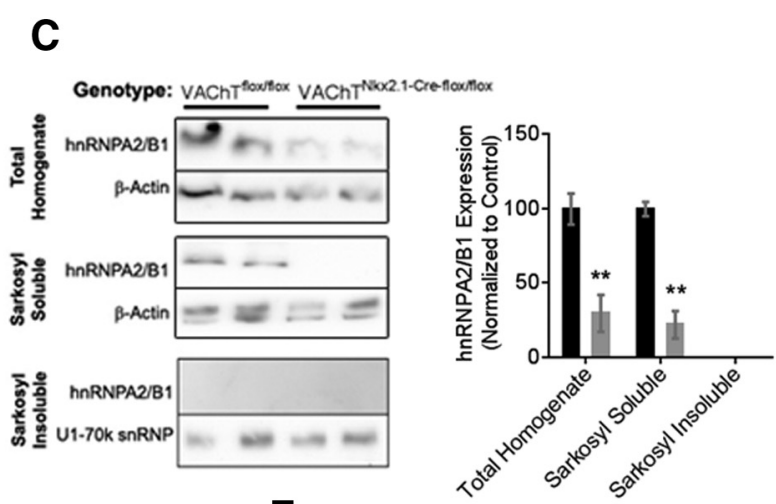

$\mathbf{F}$

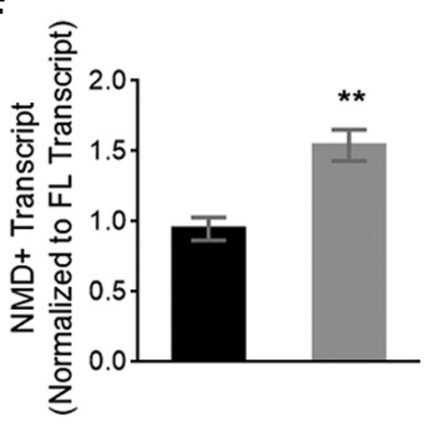

Figure 3. Mechanisms of cholinergic regulation of hnRNPA2/B1 protein levels. $A$, No change in ubiquitination status of hnRNPA2/B1 was observed when hnRNPA2/B1 from the hippocampus of VAChT deficient mice ( $p=0.3067$; control, $n=7$; VAChT ${ }^{\text {Nkx2.1- - cre-flox/flox }}$ mice, $n=6$ ) was immunoprecipitated using anti-hnRNPA2/B1 antibody and probed with anti-ubiquitin antibody. $\boldsymbol{B}$, Sarkosyl insolubility assay shows no aggregation of hnRNPA2/B1 in VAChT ${ }^{\text {Nkx2.1-Cre-flox/flox }}$ mice $(n=4)$. C, Transcript level of hnRNPA2/B1 in the RNA-Seq data set $(p=0.9124$, FDR $=1)$. $\boldsymbol{D}$, Diagram of the alternative splicing in the 3'UTR of hnRNPA2/B1 transcripts. The FL transcript is predicted to be stable and undergo translation, whereas the NMD-sensitive transcript is not (Bonomi et al., 2013). Primers used to assay this event are show in the schematic. $E$, Increase in the proportion of NMD + hnRNPA2/B1 transcripts in the hippocampus of VAChT $T^{\mathrm{Nkx2} .1-\text {-Cre-flox/flox }}$ mice $(n=4)$. ${ }^{* *} p<0.01$.

adult VAChT ${ }^{\text {flox/flox }}$ mice using AAV8-Cre virus. AAV8-Creinjected mice showed interrelated decline of both VAChT and hnRNPA2/B1 proteins, whereas AAV8-GFP-injected mice did not (Fig. 1B). There was a significant relationship between VAChT and hnRNPA2/B1 levels $\left(r^{2}=0.755, p<0.001\right.$; Fig. $\left.1 B\right)$. In addition, we tested whether, in the striatum, elimination of cholinergic tone would affect hnRNPA2/B1 expression by using VAChT $^{\text {D2-Cre-flox/flox }}$ mice with selective striatal VAChT deficiency (Guzman et al., 2011). These mice showed no changes in hnRNPA2/B1 in their striatum (Fig. 1C), indicating hippocampal specificity of these effects.

If expression of hnRNPA2/B1 is a cholinergic-regulated process, one would expect that increased cholinergic tone should have opposite effects than those observed by decreased VAChT expression. ChAT-ChR2-EGFP mice overexpress $\mathrm{VAChT}$ in the hippocampus and consequently present increased cholinergic tone and ACh release (Kolisnyk et al., 2013b). These mice present increased hnRNPA2/B1 protein levels (Fig. 1D), suggesting that VAChT levels critically regulate hnRNPA2/B1 expression.

Decline of hnRNPA2/B1 could be solely related to VAChT depletion, or, alternatively, it could reflect the functional loss of ACh signaling in the CNS. To distinguish between these possibilities, we tested the hippocampus of TgR mice overexpressing soluble AChE (Shaked et al., 2009), which causes cholinergic insufficiency. TgR mice showed decrease in hnRNPA2/B1 levels similar to mice with decreased VAChT (Fig. 1E), suggesting that ACh synaptic levels are causally involved in the regulation of hnRNPA2/B1 expression. Cre expression by itself had no effect on hnRNPA2/B1 levels, as can be seen when we compared ex- pression of hnRNPA2/B1 in the hippocampus of Nkx2.1-Cre and WT mice (Fig. $1 F$ ). Together, these data give strong support for the hypothesis that hnRNPA2/B1 is a cholinergic-regulated splicing factor.

RNA binding proteins such as hnRNPA2/B1 are predominantly expressed in the nucleus, but they can accumulate in the cytoplasm and cause neuronal toxicity (Wolozin, 2012; Kim et al., 2013). We therefore determined by immunofluorescence staining whether the localization of hnRNPA2/B1 is changed in response to decreased cholinergic tone. Compared to controls, VAChT $^{\text {Nkx2.1-Cre-flox/flox }}$ had a decrease in hnRNPA2/B1 immunostaining in the CA1, CA3, and dentate gyrus regions of the hippocampus (Fig. $2 A-D$ ). hnRNPA2/B1 was present mainly in the nucleus of both neurons (labeled by NeuN; Fig. $2 A-D$ ) as well as in astrocytes $(E)$ in control mice. We did not observe any shift in the localization of hnRNPA2/B1 in VAChT-deficient mice, only an overall decrease in the levels of staining. To confirm these observations, we used subcellular fractionation to assess whether VAChT $^{\text {Nkx2.1-Cre-flox/flox }}$ mice show changes in hnRNPA2/B1 distribution between the nuclear and cytoplasmic fractions (Fig. $2 F)$. In both control and VAChT-deficient mice, hnRNPA2/B1 was predominantly nuclear, following the distribution of the nuclear enzyme PIAS1 (Soares et al., 2013). However, $\mathrm{VAChT}^{\mathrm{Nkx} 2.1 \text {-Cre-flox/flox }}$ mice showed consistently reduced nuclear hnRNPA2/B1 levels (Fig. 2F).

\section{Mechanisms of cholinergic modulation of hnRNPA2/B1}

To investigate mechanisms by which cholinergic tone may regulate the levels of hnRNPA2/B1 protein, we evaluated ubiquitination, a modification that can facilitate protein deg- 

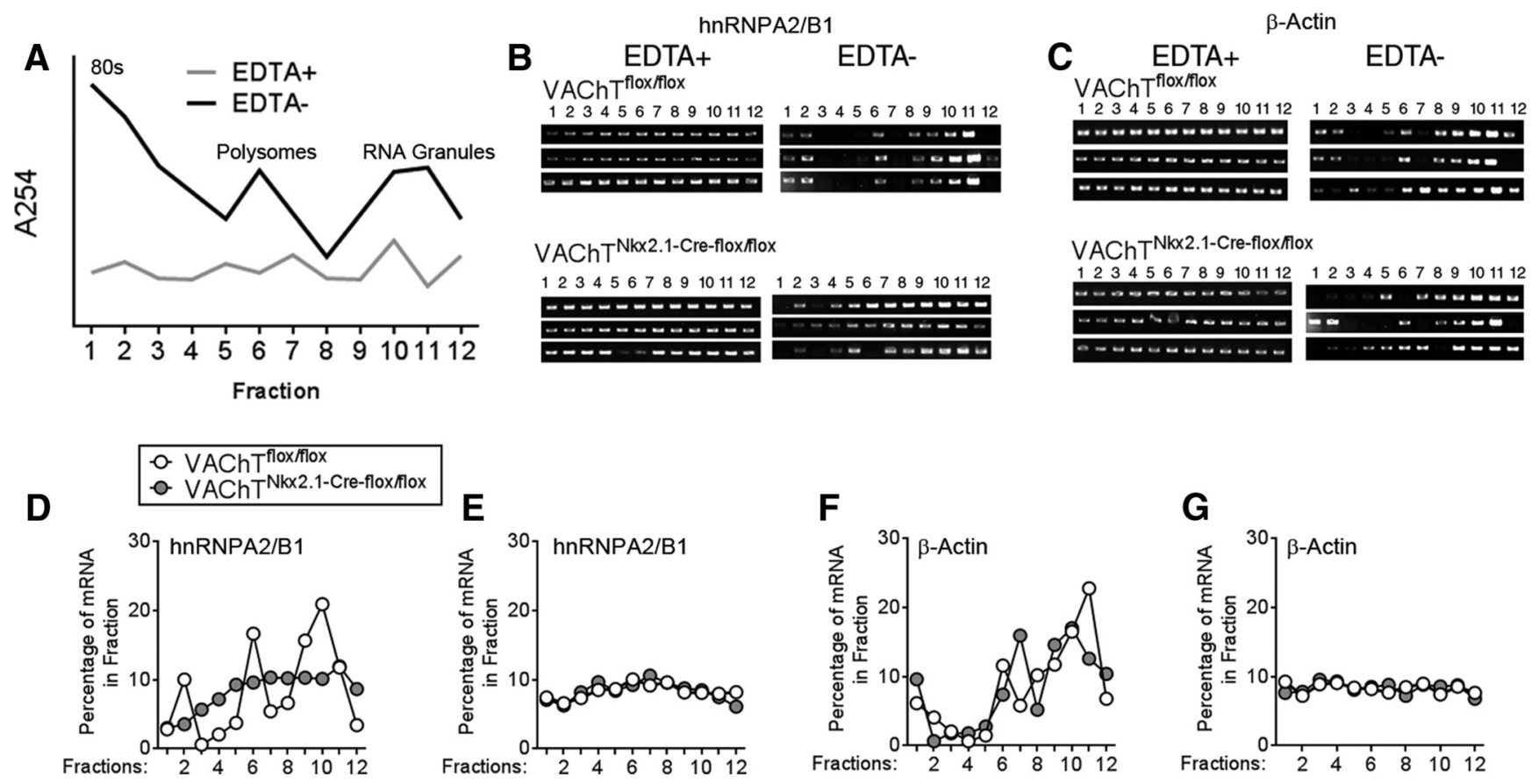

Figure 4. Forebrain cholinergic tone regulates translation of hNRNPA2/B1 in the hippocampus. A, Hippocampal brain tissue was fractionated on a linear sucrose gradient. Fractions were collected and analyzed by spectrophotometry to determine position of the monosome (80s), polysomes, and RNA granules. $B, R T-P C R$ of hnRNPA2/B1 transcripts in VAChT flox/flox and VAChT Nkx2.1-Cre-flox/flox mice in the absence or presence of EDTA. C, RT-PCR of $\beta$-actin transcripts in VAChT ${ }^{\text {flox/flox }}$ and VAChT ${ }^{\mathrm{Nkx2} .1-\text {-re-flox/flox }}$ mice in the absence or presence of EDTA. D, E, Quantification of data for the hnRNPA2/B1 transcripts from the three differentVAChT-deficient and three control mice in the absence or presence of EDTA.F, G, Quantification results for $\beta$-actin transcripts from the three different VAChT-deficient and three control mice in the absence or presence of EDTA. The numbers 1-12 are the fraction numbers. The values plotted are averaged from gels in $\boldsymbol{C}$. Data shown are means.

radation by the proteasome (Hochstrasser, 1996). Immunoprecipitated hnRNPA2/B1 from the hippocampi of controls

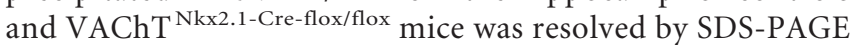
and probed with ubiquitin antibodies. VAChT-deficient mice showed no change in ubiquitination status of hnRNPA2/B1 protein when normalized to total hnRNPA2/B1 protein levels (Fig. 3A).

We also examined whether cholinergic tone affects aggregation of hnRNPA2/B1. Notably, hnRNPA2/B1 has a prion-like domain that favors increased aggregation when mutated (Kim et al., 2013). Protein aggregation was investigated by fractionating hippocampal extracts into sarkosyl-soluble and sarkosyl-insoluble fractions (Fig. 3B). In both controls and VAChT-deficient mice, hnRNPA2/B1 was mainly present in soluble fractions, unlike the U1-70k small nuclear ribonucleoprotein, which has been shown to be present in insoluble fractions (Bai et al., 2013; Fig. 3B). This result excluded the option that cholinergic tone increases aggregation of hnRNPA2/B1. Interestingly, despite different levels of hnRNPA2/B1 protein expression, both control and VAChT-deficient mice exhibited similar hnRNPA2/B1 mRNA levels as determined by RNA sequencing (Fig. 3C), as observed in AD brains (Berson et al., 2012).

It was reported previously that protein levels of hnRNPA2/B1 are directly proportional to changes in the RNA editing of the $3^{\prime}$ UTR of its mRNA, with a shift away from a nonsense-mediated decay (NMD)-sensitive transcript increasing protein levels (Bonomi et al., 2013; Fig. 3D). We evaluated by qPCR the ratio of NMD-sensitive to NMD-insensitive versions of the hnRNPA2/B1 transcript in the hippocampus of VAChT ${ }^{\text {Nkx2.1-Cre-flox/flox }}$ mice. Compared to controls, we observed a significant shift toward the NMD+ product in VAChT-deficient mice (Fig. 3E).

We then tested whether cholinergic tone modulation of NMD+ transcript could regulate hnRNPA2/B1 protein expression levels by limiting protein translation. For this, we studied the recruitment of
hnRNPA2/B1 mRNA to ribosomes. Ribonucleotide-protein complexes (RNPs) were isolated from hippocampal lysates, and sucrose density gradient fractionation was used to separate polyribosomes from large neuronal RNA granules (Fig. 4A; Wagnon et al., 2012). Distribution of hnRNPA2/B1 transcripts in individual fractions was determined by RT-PCR in three individual mice of each genotype (Fig. $4 B, C$ ). In control mice, hnRNPA2/B1 mRNAs associated with polysomes and RNA granules, and treatment with EDTA, which dissociates mRNA from polysomes, equally distributed hnRNPA2/B1 mRNAs across fractions (Fig. 4D,E). However, in $\mathrm{VAChT}^{\mathrm{Nkx} 2.1-\mathrm{Cre} \text {-flox/flox }}$ mice, distribution of hnRNPA2/B1 mRNAs was widespread throughout the fractions, resembling the distribution observed after EDTA treatment (Fig. 4D,E). The abundant $\beta$-actin mRNA remained unaltered between genotypes, demonstrating specificity toward hnRNPA2/B1 (Fig. $3 F, G$ ). These results indicate that decreased cholinergic tone leads to diminished translational capacity of hnRNPA2/B1 mRNA transcripts to modulate the efficiency of hnRNPA2/B1 protein translation.

\section{Muscarinic signaling regulates hnRNPA2/B1 translation by an NMD mechanism}

To further understand how cholinergic signaling regulates hnRNPA2/B1 levels, we treated neuronal hippocampal cultures from wild-type mice with the cholinergic mimetic carbachol ( $10 \mu \mathrm{M}$; Fig. $5 A, B)$. This treatment effectively increased hnRNPA $2 / B 1$ protein levels in immunofluorescence and immunoblot experiments, and this effect could be blocked by muscarinic, but not by nicotinic antagonist treatment (Fig. 5C).

To study the contribution of muscarinic receptor subtypes, we evaluated hnRNPA2/B1 levels in the hippocampus of muscarinic receptor knock-out mice. Compared to wild-type mice, M1, but not M4, receptor knock-out mice showed a decrease in hnRNPA2/B1 protein levels resembling that in VAChT ${ }^{\text {Nkx2.1-Cre-flox/flox }}$ 
A
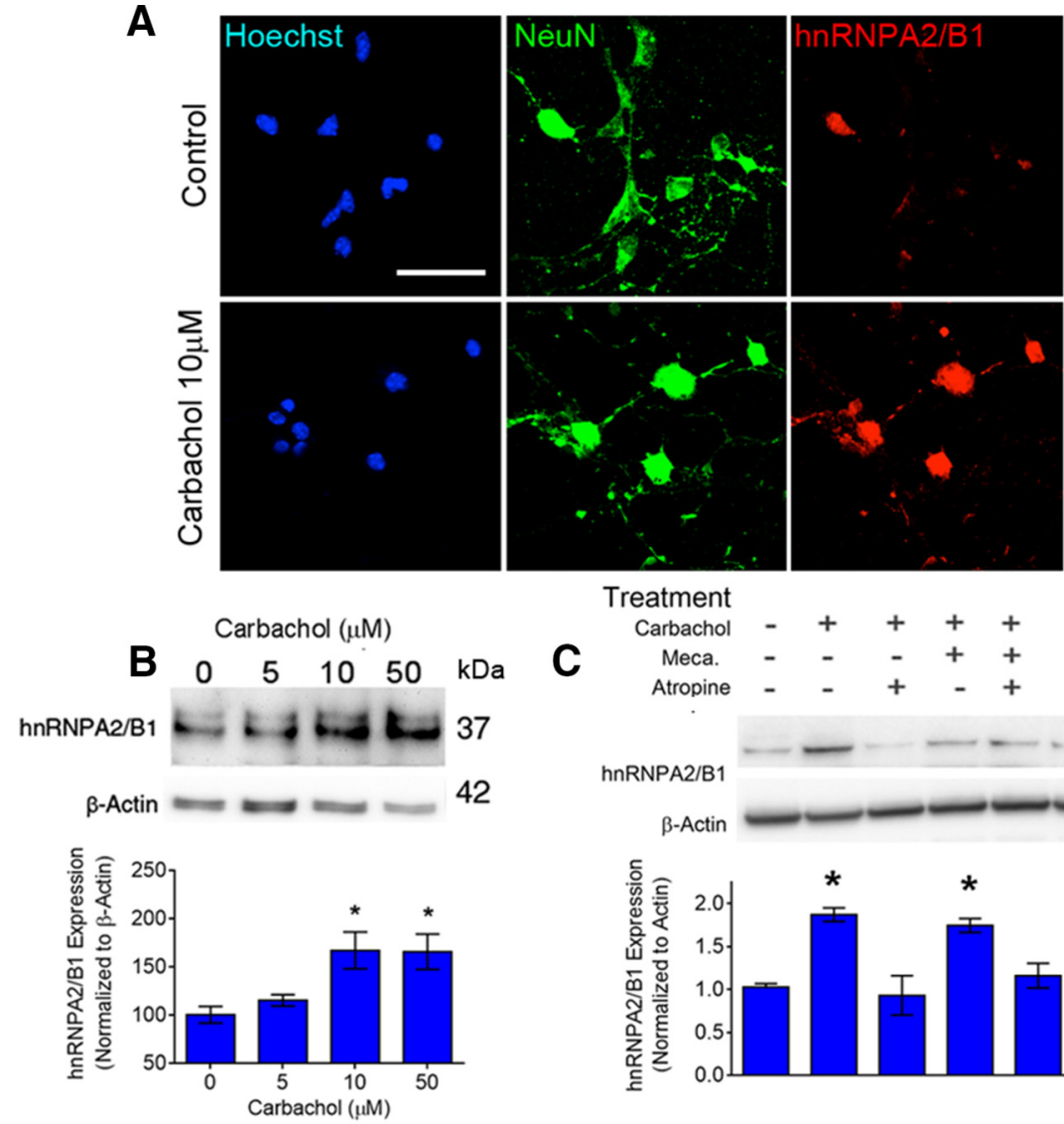

C $\begin{array}{cccccccccc}\text { Carbachol } & - & + & + & + & + & - & - & - & \\ \text { Meca. } & - & - & - & + & + & - & + & + & \\ \text { Atropine } & - & - & + & - & + & + & - & + & \mathrm{kDa}\end{array}$ 7 hnRNPA2/B1
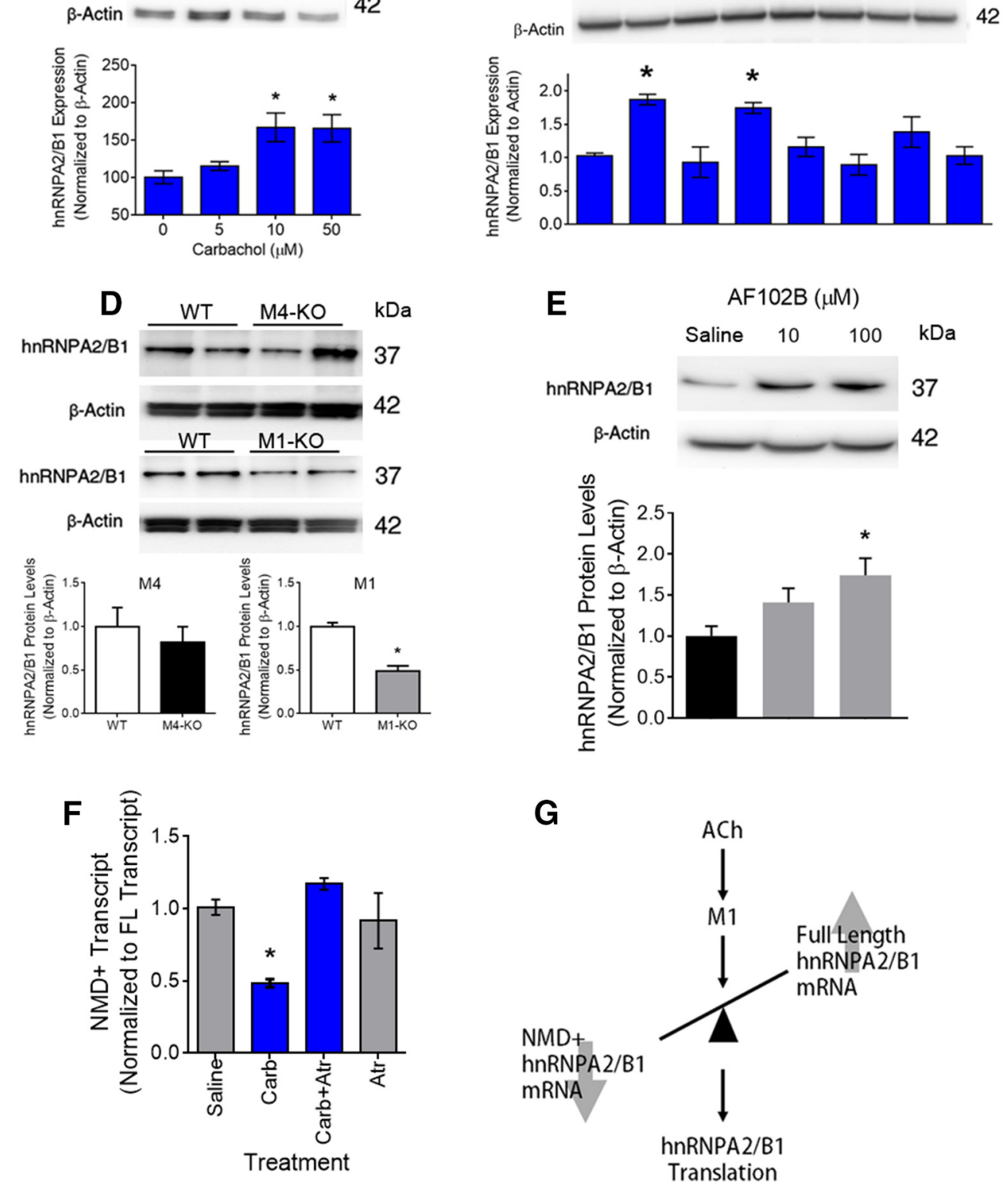
mice (Fig. 5D). Together, these experiments suggest that decreased cholinergic tone, likely due to insufficient M1 receptor activation, changes hnRNPA2/B1 protein levels by regulating mRNA translation.

To further investigate the importance of M1 muscarinic receptors in the regulation of hnRNPA2/B1 protein levels in hippocampal neurons, we treated neuronal hippocampal cultures from wild-type mice with the M1 muscarinic agonist AF102B (Fisher et al., 1989). Compared to saline-treated neurons, those treated with $100 \mu \mathrm{M}$ of AF102B showed a significant increase in protein levels of hnRNPA2/B1 (Fig. 5E).

We then evaluated whether in vitro cholinergic regulation also changes the NMD+ product. Compared to saline treatment, carbachol shifted the expression of hnRNPA2/B1 RNA toward the NMD insensitive full-length mRNA product (Fig. $5 F$ ). Furthermore, cotreatment with atropine blocked this effect and returned the ratio to control levels, similar to what we observed for hnRNPA2/B1 protein levels (Fig. 5 C). These data suggest that the ratio of NMD + hnRNPA2/B1 gene products predicts change in protein levels, and that the regulation of NMD sensitivity is dependent on muscarinic signaling.

\section{Discussion}

In this study, we combined a variety of in vivo and in vitro techniques to evaluate the contribution of cholinergic signaling to expression levels of hippocampal hnRNPA2/B1 protein. Using a number of mouse lines, we demonstrated that hnRNPA2/B1 protein levels in the hippocampus are exquisitely sensitive to changes in cholinergic tone.

Interestingly, we observed no change in hnRNPA2/B1 protein levels in striatum- specific VAChT mutants, whereas there is a body of evidence that cholinergic signaling can affect the levels of this protein in both cortical and hippocampal regions in vivo (Berson et al., 2012; Kolisnyk et al., 2013a). Given these findings, it is likely that it is an intrinsic property of the target cells themselves that dictate their change in hnRNPA2/B1 translation in response to cholinergic activity. Our results highlight the critical role of the Gq coupled M1 muscarinic receptor in governing hnRNPA2/B1 protein levels.

Unlike the rare hnRNPA2/B1 mutation that increases aggregation and nuclear exclusion (Kim et al., 2013), we did not find aggregation of hnRNPA2/B1 in mice with forebrain cholinergic deficiency, suggesting that in these mice, and likely in $\mathrm{AD}$ brains, hnRNPA2/B1 dysfunction occurs by a separate and distinct mechanism. Furthermore, we did not see an increase in ubiquitination, suggesting that changes in hnRNPA2/B1 protein levels do not occur at the posttranslational level. In line with this, we found

\section{$\leftarrow$}

Figure 5. Muscarinic regulation of hnRNPA2/B1 translation. $A, B$, Representative immunofluorescence images $(\boldsymbol{A})$ and Western blots $(\boldsymbol{B})$ with quantification of hnRNPA2/B1 protein levels in primary hippocampal neurons after treatment with carbachol for $48 \mathrm{~h}$. hnRNPA2/B1 expression was normalized to actin $(n=3)$. C, Representative Western blot and quantification of hnRNPA2/B1 expression in primary hippocampal neurons after treatment with carbachol, mecamylamine (meca.), and atropine. hnRNPA2/B1 expression was normalized to actin ( $n=$ 4). The values plotted are averaged from the gels of each individual experiment. $\boldsymbol{D}$, Representative Western blot and quantification of hnRNPA2/B1 expression in hippocampal tissue of M4 muscarinic knock-out mice (M4-K0; $n=7$ ) and M1 receptor knock-out mice (M1-K0; control, $n=7 ; \mathrm{M} 1-\mathrm{K} 0$ mice, $n=8)$. $\boldsymbol{E}$, M1 muscarinic receptor agonist AF102B significantly increased hnRNPA2/B1 protein levels in primary hippocampal cultures $(n=5) . \boldsymbol{F}$, Increased expression of the full-length hnRNPA2/B1 transcripts of cells treated with carbachol is blocked by the administration of atropine $(n=5)$. G, Proposed model wherein muscarinic M1 receptors signaling would shift the ratio of hnRNPA2/B transcripts, favoring the full length transcripts, and therefore increase translation of the protein. Data are mean \pm SEM. ${ }^{*} p<0.05$. that it may in fact be abnormal translation that drives regulation of hnRNPA2/B1.

A common mechanism for the regulation of the translation of RNA binding proteins (RBPs) is regulation by unproductive splicing and translation (RUST), where the alternative spicing of a transcript affects its translation efficiency (Lareau et al., 2007; McGlincy and Smith, 2008). This may serve as a potential mechanism for cholinergic control of the translation of this RBP. Accordingly, we found that the levels of hnRNPA2/B1 transcripts were maintained in cholinergic-deficient mice or AD brains (Berson et al., 2012), but hnRNPA2/B1 translation was selectively decreased. Notably, hnRNPA2/B1 has been shown to be autoregulated by a RUST mechanism involving alternative splicing in its $3^{\prime}$ untranslated region that leads to NMD driven by mTOR1C (McGlincy et al., 2010; Dempsey, 2012), which is a key effector of muscarinic receptor signaling (Slack and Blusztajn, 2008). Correspondingly, we found that cholinergic control of hnRNPA2/B1 translation is mediated by M1 muscarinic receptors (Fig. $5 G$ ).

Targeting the interactions between RBPs and RNA may serve as a new potential therapeutic avenue to restore the RNA-editing deficits observed in neurodegenerative diseases (Tollervey et al., 2011; Berson et al., 2012; Bai et al., 2013; Qian and Liu, 2014). A number of substances, including regularly prescribed antibiotics, have been shown to nonselectively alter alternative splicing in the brain (Graveley, 2005; Tollervey et al., 2011; Kole et al., 2012); however, this approach lacks the ability to specifically target "impaired" RBP-RNA interactions.

Cholinergic failure is one of the hallmarks of $\mathrm{AD}$, with the basal forebrain cholinergic system being heavily affected by the disease (Whitehouse et al., 1982). Data from the Alzheimer's Disease Neuroimaging Initiative has linked cholinergic failure in $\mathrm{AD}$ to both pathological outcomes (Teipel et al., 2014) as well as cognitive impairments in AD (Grothe et al., 2014). Further evidence for the importance of cholinergic signaling to the etiology of $\mathrm{AD}$ comes from clinical evidence that the long-term use of anticholinergic medication, specifically antimuscarinic drugs, significantly increases the risk of developing dementia (Gray et al., 2015). Interestingly, administration of antimuscarinic agents to AD patients exacerbates their symptoms (Lim et al., 2015). Together, these results suggest a crucial role for cholinergic tone in $\mathrm{AD}$, with specific importance of muscarinic signaling.

The main pathological hallmarks of $\mathrm{AD}$ are the accumulation of $A \beta$ plaques and of hyperphosphorylated tau (Huang and Jiang, 2009). M1 muscarinic signaling has been linked to both of these processes. Activation of the receptor has been shown to alter tau phosphorylation both in vitro (Sadot et al., 1996) and in vivo (Genis et al., 1999). Moreover, deletion of M1 muscarinic receptors increases $\mathrm{A} \beta$ related pathology in a transgenic mouse model overexpressing mutated APP (Davis et al., 2010). Furthermore, $\mathrm{M} 1$ agonists have been shown to reverse $\mathrm{A} \beta$ related pathology in mouse models of AD (Caccamo et al., 2006). These findings suggest that $\mathrm{M} 1$ receptors are key mediators of $\mathrm{AD}$ pathology. How hnRNPA2/B1 protein expression may contribute to pathology remains to be determined.

Cholinergic failure also plays an important role in one of the most important and apparent cognitive deficits of $\mathrm{AD}$, memory loss (Bartus et al., 1982). There is a strong correlation between loss of basal forebrain cholinergic neurons and cognitive functioning in $\mathrm{AD}$ patients. Furthermore, mice with a forebrain specific deletion of VAChT have severe deficits in performance on the paired-associates learning touch-screen task (Al-Onaizi et al., 2016), a rodent version of the Cambridge Neuropsychological Test Automated Battery tests used in humans, which has been 
shown to be selective for the memory impairments in $\mathrm{AD}$ patients (Egerhazi et al., 2007). Importantly, lentiviral mediated knockdown of hnRNPA2/B1 also produced cognition impairments in mice (Berson et al., 2012).

Together, our findings indicate an intricate relationship between M1 muscarinic signaling and hnRNPA2/B1 translation. These findings lay the ground work for new therapeutic avenues for the treatment of AD. Specifically, they point to the potential of M1 muscarinic positive allosteric modulators to improve longterm changes in RNA metabolism and cognitive deficits due to cholinergic malfunction in AD. Noteworthy M1 muscarinic positive allosteric modulators have shown promising results to improve cognition in nonhuman primates (Lange et al., 2015).

\section{References}

Al-Onaizi MA, Parfitt GM, Kolisnyk B, Law CS, Guzman MS, Barros DM, Leung LS, Prado MA, Prado VF (2016) Regulation of cognitive processing by hippocampal cholinergic tone. Cereb Cortex. Advance online publication. Retrieved January 22, 2016. doi:10.1093/cercor/bhv349.

Bai B, Hales CM, Chen PC, Gozal Y, Dammer EB, Fritz JJ, Wang X, Xia Q, Duong DM, Street C, Cantero G, Cheng D, Jones DR, Wu Z, Li Y, Diner I, Heilman CJ, Rees HD, Wu H, Lin L, et al. (2013) U1 small nuclear ribonucleoprotein complex and RNA splicing alterations in Alzheimer's disease. Proc Natl Acad Sci U S A 110:16562-16567. CrossRef Medline

Bartus RT, Dean RL 3rd, Beer B, Lippa AS (1982) The cholinergic hypothesis of geriatric memory dysfunction. Science 217:408-414. CrossRef Medline

Beraldo FH, Soares IN, Goncalves DF, Fan J, Thomas AA, Santos TG, Mohammad AH, Roffé M, Calder MD, Nikolova S, Hajj GN, Guimaraes AL, Massensini AR, Welch I, Betts DH, Gros R, Drangova M, Watson AJ, Bartha R, Prado VF, Martins VR, et al. (2013) Stress-inducible phosphoprotein 1 has unique cochaperone activity during development and regulates cellular response to ischemia via the prion protein. FASEB J 27 : 3594-3607. CrossRef Medline

Berson A, Barbash S, Shaltiel G, Goll Y, Hanin G, Greenberg DS, Ketzef M, Becker AJ, Friedman A, Soreq H (2012) Cholinergic-associated loss of hnRNP-A/B in Alzheimer's disease impairs cortical splicing and cognitive function in mice. EMBO Mol Med 4:730-742. CrossRef Medline

Black DL (2003) Mechanisms of alternative pre-messenger RNA splicing. Annu Rev Biochem 72:291-336. CrossRef Medline

Blencowe BJ (2006) Alternative splicing: new insights from global analyses. Cell 126:37-47. CrossRef Medline

Bonomi S, di Matteo A, Buratti E, Cabianca DS, Baralle FE, Ghigna C, Biamonti G (2013) HnRNP A1 controls a splicing regulatory circuit promoting mesenchymal-to-epithelial transition. Nucleic Acids Res 41: 8665-8679. CrossRef Medline

Caccamo A, Oddo S, Billings LM, Green KN, Martinez-Coria H, Fisher A, LaFerla FM (2006) M1 receptors play a central role in modulating ADlike pathology in transgenic mice. Neuron 49:671-682. CrossRef Medline

Choo YS, Zhang Z (2009) Detection of protein ubiquitination. J Vis Exp pii:1293. CrossRef

Dajas-Bailador F, Wonnacott S (2004) Nicotinic acetylcholine receptors and the regulation of neuronal signalling. Trends Pharmacol Sci 25: 317-324. CrossRef Medline

Davis AA, Fritz JJ, Wess J, Lah JJ, Levey AI (2010) Deletion of M1 muscarinic acetylcholine receptors increases amyloid pathology in vitro and in vivo. J Neurosci 30:4190-4196. CrossRef Medline

Dempsey JM (2012) SRPK2 phosphorylation by the AGC kinases, and mTORC1 regulation of alternative splicing. Doctoral dissertation, Harvard University.

Dreyfuss G, Matunis MJ, Piñol-Roma S, Burd CG (1993) hnRNP proteins and the biogenesis of mRNA. Annu Rev Biochem 62:289-321. CrossRef Medline

Dubois B, Chupin M, Hampel H, Lista S, Cavedo E, Croisile B, Louis Tisserand G, Touchon J, Bonafe A, Ousset PJ, Ait Ameur A, Rouaud O, Ricolfi F, Vighetto A, Pasquier F, Delmaire C, Ceccaldi M, Girard N, Dufouil C, et al. (2015) Donepezil decreases annual rate of hippocampal atrophy in suspected prodromal Alzheimer's disease. Alzheimers Dement 11:1041-1049. CrossRef Medline

Egerhazi A, Berecz R, Bartok E, Degrell I (2007) Automated Neuropsycho- logical Test Battery (CANTAB) in mild cognitive impairment and in Alzheimer's disease. Progress Neuropsychopharmacol Biol Psychiatry 31: 746-751. CrossRef

Fisher A, Brandeis R, Pittel Z, Karton I, Sapir M, Dachir S, Levy A, Heldman E (1989) (+-)-cis-2-methyl-spiro(1,3-oxathiolane-5,3') quinuclidine (AF102B): a new M1 agonist attenuates cognitive dysfunctions in AF64Atreated rats. Neurosci Lett 102:325-331. CrossRef Medline

Genis I, Fisher A, Michaelson DM (1999) Site-specific dephosphorylation of tau of apolipoprotein E-deficient and control mice by M1 muscarinic agonist treatment. J Neurochem 72:206-213. Medline

Gomeza J, Zhang L, Kostenis E, Felder C, Bymaster F, Brodkin J, Shannon H, Xia B, Deng C, Wess J (1999) Enhancement of D1 dopamine receptormediated locomotor stimulation in $\mathrm{M}(4)$ muscarinic acetylcholine receptor knockout mice. Proc Natl Acad Sci U S A 96:10483-10488. CrossRef Medline

Graveley BR (2005) Small molecule control of pre-mRNA splicing. RNA 11:355-358. CrossRef Medline

Gray SL, Anderson ML, Dublin S, Hanlon JT, Hubbard R, Walker R, Yu O, Crane PK, Larson EB (2015) Cumulative use of strong anticholinergics and incident dementia: a prospective cohort study. JAMA Int Med 175: 401-407. CrossRef

Grothe MJ, Ewers M, Krause B, Heinsen H, Teipel SJ, Alzheimer's Disease Neuroimaging Initiative (2014) Basal forebrain atrophy and cortical amyloid deposition in nondemented elderly subjects. Alzheimers Dement 10:S344-S353. CrossRef Medline

Guzman MS, De Jaeger X, Raulic S, Souza IA, Li AX, Schmid S, Menon RS, Gainetdinov RR, Caron MG, Bartha R, Prado VF, Prado MA (2011) Elimination of the vesicular acetylcholine transporter in the striatum reveals regulation of behaviour by cholinergic-glutamatergic cotransmission. PLoS Biol 9:e1001194. CrossRef Medline

Hamilton SE, Loose MD, Qi M, Levey AI, Hille B, McKnight GS, Idzerda RL, Nathanson NM (1997) Disruption of the $\mathrm{m} 1$ receptor gene ablates muscarinic receptor-dependent $\mathrm{M}$ current regulation and seizure activity in mice. Proc Natl Acad Sci U S A 94:13311-13316. CrossRef Medline

Han SP, Friend LR, Carson JH, Korza G, Barbarese E, Maggipinto M, Hatfield JT, Rothnagel JA, Smith R (2010) Differential subcellular distributions and trafficking functions of hnRNP A2/B1 spliceoforms. Traffic 11: 886-898. CrossRef Medline

Hochstrasser M (1996) Ubiquitin-dependent protein degradation. Annu Rev Genet 30:405-439. CrossRef Medline

Huang HC, Jiang ZF (2009) Accumulated amyloid-beta peptide and hyperphosphorylated tau protein: relationship and links in Alzheimer's disease. J Alzheimers Dis 16:15-27. Medline

Kim HJ, Kim NC, Wang YD, Scarborough EA, Moore J, Diaz Z, MacLea KS, Freibaum B, Li S, Molliex A, Kanagaraj AP, Carter R, Boylan KB, Wojtas AM, Rademakers R, Pinkus JL, Greenberg SA, Trojanowski JQ, Traynor BJ, Smith BN, et al. (2013) Mutations in prion-like domains in hnRNPA2B1 and hnRNPA1 cause multisystem proteinopathy and ALS. Nature 495:467-473. CrossRef Medline

Kole R, Krainer AR, Altman S (2012) RNA therapeutics: beyond RNA interference and antisense oligonucleotides. Nat Rev Drug Discov 11:125-140. Medline

Kolisnyk B, Al-Onaizi MA, Hirata PH, Guzman MS, Nikolova S, Barbash S, Soreq H, Bartha R, Prado MA, Prado VF (2013a) Forebrain deletion of the vesicular acetylcholine transporter results in deficits in executive function, metabolic, and RNA splicing abnormalities in the prefrontal cortex. J Neurosci 33:14908-14920. CrossRef Medline

Kolisnyk B, Guzman MS, Raulic S, Fan J, Magalhães AC, Feng G, Gros R, Prado VF, Prado MA (2013b) ChAT-ChR2-EYFP mice have enhanced motor endurance but show deficits in attention and several additional cognitive domains. J Neurosci 33:10427-10438. CrossRef Medline

Lange HS, Cannon CE, Drott JT, Kuduk SD, Uslaner JM (2015) The M1 muscarinic positive allosteric modulator PQCA improves performance on translatable tests of memory and attention in rhesus monkeys. J Pharmacol Exp Ther 355:442-450. CrossRef Medline

Lareau LF, Brooks AN, Soergel DA, Meng Q, Brenner SE (2007) The coupling of alternative splicing and nonsense-mediated mRNA decay. Adv Exp Med Biol 623:190-211. CrossRef Medline

Lim YY, Maruff P, Schindler R, Ott BR, Salloway S, Yoo DC, Noto RB, Santos CY, Snyder PJ (2015) Disruption of cholinergic neurotransmission exacerbates Abeta-related cognitive impairment in preclinical Alzheimer's disease. Neurobiol Aging 36:2709-2715. CrossRef Medline 
Martins-Silva C, De Jaeger X, Guzman MS, Lima RD, Santos MS, Kushmerick C, Gomez MV, Caron MG, Prado MA, Prado VF (2011) Novel strains of mice deficient for the vesicular acetylcholine transporter: insights on transcriptional regulation and control of locomotor behavior. PLoS One 6:e17611. CrossRef Medline

McGlincy NJ, Smith CW (2008) Alternative splicing resulting in nonsensemediated mRNA decay: what is the meaning of nonsense? Trends Biochem Sci 33:385-393. CrossRef Medline

McGlincy NJ, Tan LY, Paul N, Zavolan M, Lilley KS, Smith CW (2010) Expression proteomics of UPF1 knockdown in HeLa cells reveals autoregulation of hnRNP A2/B1 mediated by alternative splicing resulting in nonsense-mediated mRNA decay. BMC Genomics 11:565. CrossRef Medline

Novarino G, Fenstermaker AG, Zaki MS, Hofree M, Silhavy JL, Heiberg AD, Abdellateef M, Rosti B, Scott E, Mansour L, Masri A, Kayserili H, Al-Aama JY, Abdel-Salam GM, Karminejad A, Kara M, Kara B, Bozorgmehri B, Ben-Omran T, Mojahedi F, et al. (2014) Exome sequencing links corticospinal motor neuron disease to common neurodegenerative disorders. Science 343:506-511. CrossRef Medline

Qian W, Liu F (2014) Regulation of alternative splicing of tau exon 10. Neurosci Bull 30:367-377. CrossRef Medline

Ribeiro FM, Ferreira LT, Marion S, Fontes S, Gomez M, Ferguson SS, Prado MA, Prado VF (2007) SEC14-like protein 1 interacts with cholinergic transporters. Neurochem Int 50:356-364. CrossRef Medline

Sadot E, Gurwitz D, Barg J, Behar L, Ginzburg I, Fisher A (1996) Activation of $\mathrm{m} 1$ muscarinic acetylcholine receptor regulates tau phosphorylation in transfected PC12 cells. J Neurochem 66:877-880. Medline

Shaked I, Meerson A, WolfY, Avni R, Greenberg D, Gilboa-Geffen A, Soreq H (2009) MicroRNA-132 potentiates cholinergic anti-inflammatory signaling by targeting acetylcholinesterase. Immunity 31:965-973. CrossRef Medline

Slack BE, Blusztajn JK (2008) Differential regulation of mTOR-dependent S6 phosphorylation by muscarinic acetylcholine receptor subtypes. J Cell Biochem 104:1818-1831. CrossRef Medline

Soares IN, Caetano FA, Pinder J, Rodrigues BR, Beraldo FH, Ostapchenko VG, Durette C, Pereira GS, Lopes MH, Queiroz-Hazarbassanov N, Cunha IW, Sanematsu PI, Suzuki S, Bleggi-Torres LF, Schild-Poulter C, Thibault
P, Dellaire G, Martins VR, Prado VF, Prado MA (2013) Regulation of stress-inducible phosphoprotein 1 nuclear retention by protein inhibitor of activated STAT PIAS1. Mol Cell Proteomics 12:3253-3270. CrossRef Medline

Soreq H (2015) Checks and balances on cholinergic signaling in brain and body function. Trends Neurosci 38:448-458. CrossRef Medline

Teipel S, Heinsen H, Amaro E Jr, Grinberg LT, Krause B, Grothe M, Alzheimer's Disease Neuroimaging Initiative (2014) Cholinergic basal forebrain atrophy predicts amyloid burden in Alzheimer's disease. Neurobiol Aging 35:482-491. CrossRef Medline

Tollervey JR, Wang Z, Hortobágyi T, Witten JT, Zarnack K, Kayikci M, Clark TA, Schweitzer AC, Rot G, Curk T, Zupan B, Rogelj B, Shaw CE, Ule J (2011) Analysis of alternative splicing associated with aging and neurodegeneration in the human brain. Genome Res 21:1572-1582. CrossRef Medline

Wagnon JL, Briese M, Sun W, Mahaffey CL, Curk T, Rot G, Ule J, Frankel WN (2012) CELF4 regulates translation and local abundance of a vast set of mRNAs, including genes associated with regulation of synaptic function. PLoS Genet 8:e1003067. CrossRef Medline

Weighardt F, Biamonti G, Riva S (1996) The roles of heterogeneous nuclear ribonucleoproteins (hnRNP) in RNA metabolism. BioEssays 18:747-756. CrossRef Medline

Whitehouse PJ, Price DL, Struble RG, Clark AW, Coyle JT, Delon MR (1982) Alzheimer's disease and senile dementia: loss of neurons in the basal forebrain. Science 215:1237-1239. CrossRef Medline

Wimo A, Jönsson L, Bond J, Prince M, Winblad B, Alzheimer Disease International (2013) The worldwide economic impact of dementia 2010. Alzheimers Dement 9:1-11.e13. Medline

Wolozin B (2012) Regulated protein aggregation: stress granules and neurodegeneration. Mol Neurodegener 7:56. CrossRef Medline

Xu Q, Tam M, Anderson SA (2008) Fate mapping Nkx2.1-lineage cells in the mouse telencephalon. J Comp Neurol 506:16-29. CrossRef Medline

Zhao S, Ting JT, Atallah HE, Qiu L, Tan J, Gloss B, Augustine GJ, Deisseroth K, Luo M, Graybiel AM, Feng G (2011) Cell type-specific channelrhodopsin-2 transgenic mice for optogenetic dissection of neural circuitry function. Nat Methods 8:745-752. CrossRef Medline 